\title{
Gully development, evolution and erosion using a landscape evolution model
}

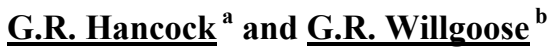 \\ ${ }^{a}$ School of Environmental and Life Sciences, The University of Newcastle, Callaghan, \\ New South Wales, 2308, Australia \\ Email: Greg.Hancock@newcastle.edu.au \\ School of Engineering, The University of Newcastle, Callaghan, \\ New South Wales, 2308, Australia
}

\begin{abstract}
Gullies are a recognised driver of landscape evolution. They are common features not just in natural landscape systems but also in agricultural and post-mining landforms. It is therefore necessary that gully initiation, development and evolution be thoroughly understood for both improved land surface process understandings but also for improved landscape management. Computer based landscape evolution models that use a mesh of grid cells to represent a catchment have the potential to model the evolution of transient features such as gullies. Landscape evolution models use a DEM and have the designed so that they adjust elevation to both erosion and deposition. Therefore they are able to better represent the effect of changing hillslope and catchment morphology on erosion. This process is dynamic. In this study the SIBERIA model is used to evaluate gully evolution. SIBERIA has been extensively used and has been shown to be able to model long-term whole-landscape evolution as well as predict hillslope and catchment scale erosion rates. This is the first evaluation of the model for its ability to predict erosion features such as gullies at the catchment scale. The results show that the model is able to largely predict gully formation as well as morphology. This is the first time that a landscape evolution model has been used to examine gully development in an undisturbed catchment.
\end{abstract}

It is important to understand gully initiation, development and evolution as they are drivers of landscape change and erode and transport considerable volumes of sediment through the channel network (Wainwright et al., 2006). They are common features not just in natural landscape systems but also in agricultural and post-mining landforms. Post-mining landforms are of particular interest as they are often constructed at steeper slopes than the original landscape and have little vegetation compared to natural surrounds. They are also constructed of unconsolidated materials and can be prone to gullying. A further important issue is that they often contain fine material from mineral processing (i.e. tailings) that can be readily eroded if exposed while metalliferous mines often have acid-generating material that requires long term coverage. Also in the case of uranium mines these materials can be radioactive. It is therefore necessary that gully initiation, development and evolution be thoroughly understood for both improved land surface process understandings but also for improved landscape management.

Many of the models developed have been developed with a single focus such as soil erosion quantification, headward growth rate prediction or gully risk assessment (Poesen et al., 2003). Computer based landscape evolution models (LEMs) offer many of the features of soil erosion and gully prediction models and can offer insights into the behaviour of landscape features such as gullies. LEMs that use a mesh of grid cells to represent a catchment were initially developed in the 1970s. With ever increasing computer processing power these models evolved to encompass larger domains and more complex processes. The models have been widely used to examine landscape development over geological time scales. They also have the potential to model the evolution of transient landforms and features such as gullies (Hancock et al., 2000; 2008).

Here the SIBERIA model is used to evaluate gully evolution in the Tin Camp Creek catchment, Northern Territory, Australia. SIBERIA has been extensively used in the region and has been shown to be able to model long-term landscape evolution (Hancock et al., 2002) as well as predict hillslope and catchment scale erosion rates (Hancock et al., 2008; 2010). This paper evaluates the model for its ability to predict transient erosion features such as gullies.

Keywords: soil erosion, landscape evolution, SIBERIA, climate variability, gully 


\section{INTRODUCTION AND STUDY SITE}

This research is part of an ongoing assessment of Landscape Evolution Models (LEMs) and their accuracy and reliability. LEMs offers the ability to examine individual landscape process spatially and temporally as various catchment controls can be held constant and a single variable changed allowing detailed analysis of form-process relations.

This paper examines gully development in the wet-dry tropics of Northern Australia. The study site, a subcatchment of the Tin Camp Creek system, Northern Territory, Australia (Figure 1) has a mean annual rainfall for the region is approximately $1400 \mathrm{~mm}$, almost all of which falls in the wet season months from November to April. Short, storms of high intensity are common, consequently fluvial erosion is the primary erosion process (Saynor et al., 2004). Generally, most of the erosion occurs during a small number of high intensity tropical storms.

Previous studies have examined gullies at Tin Camp Creek (Hancock and Evans, 2010). Reasons for the existence of such gullies are speculative and range from the presence of feral animals, such as water buffalo (introduced in the 1800 s and removed in the 1970s), pigs (introduced in the 1900s) and wild horses as well as an enhanced fire regime in the area over the last $40 \quad 000$ years. Nevertheless, there has been no intense grazing or other agricultural practices within the area as a result of the presence of Europeans. Other studies in the region have examined gully development on disturbed areas, such as waste rock dumps of the Scinto 6 former uranium mine
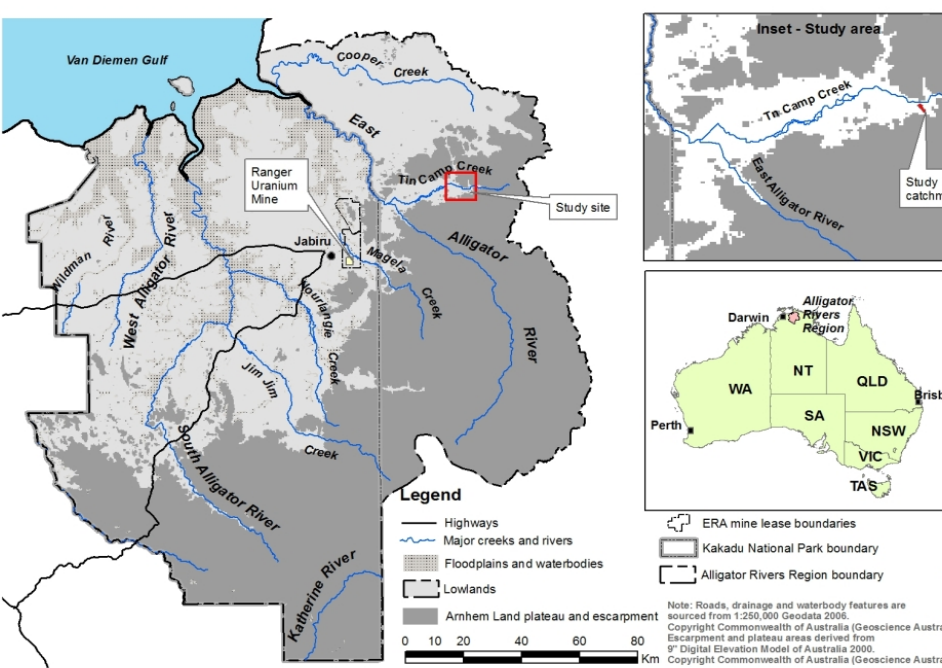

Figure 1. Location of study site.

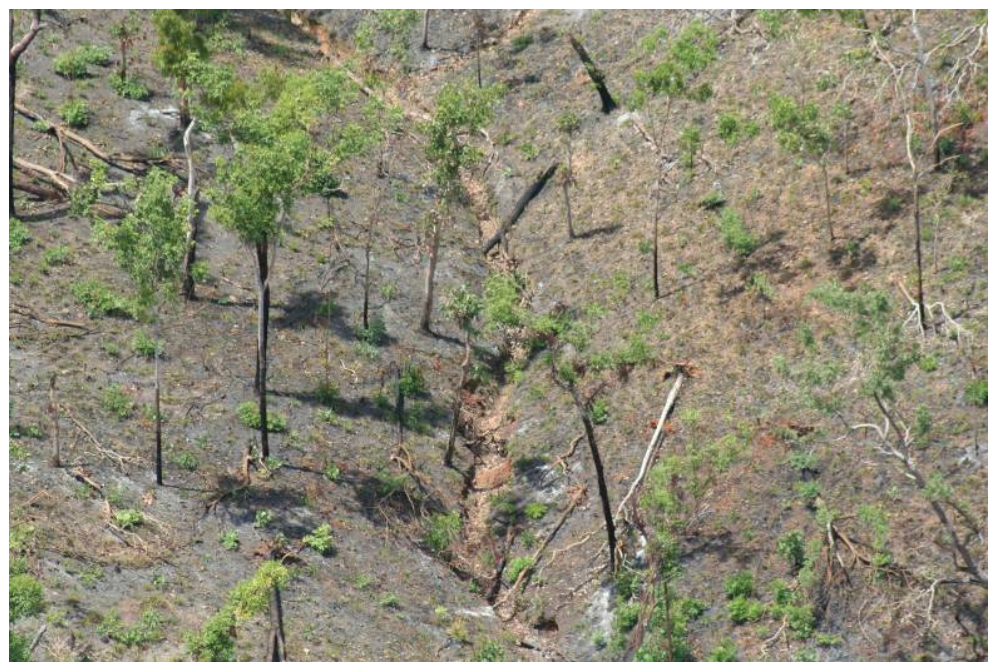

Figure 2. Typical gully in the study catchment.

(Hancock et al., 2000) and on vehicle tracks where repeated vehicle travel on burnt ground reduced the root and algal mat sandy soil, lowering critical shear stress for sediment transport (Saynor et al., 2004). This resulted in rapid and deep incisive erosion during one wet season, demonstrating that gullies can occur rapidly in this environment.

The area is presently tectonically inactive. Tin Camp Creek is part of the Ararat Land System and developed in the late Cainozoic by the retreat of the Arnhem Land escarpment, resulting in a landscape dissected by active gully erosion (Hancock and Evans, 2010). For the purposes of this study, a smaller 50 ha catchment, with features representative of many others in the area was selected (Figures 2 and 3). The catchment consists of closely dissected short, steep slopes $10-100 \mathrm{~m}$ long with gradients generally between $15-50 \%$. The soils are red loamy earths and shallow gravely loam with some micaceous silty yellow earths and minor solodic soils on alluvial flats. Much of the surface of slopes and hill crests is covered by a gravely cobble quartz. 


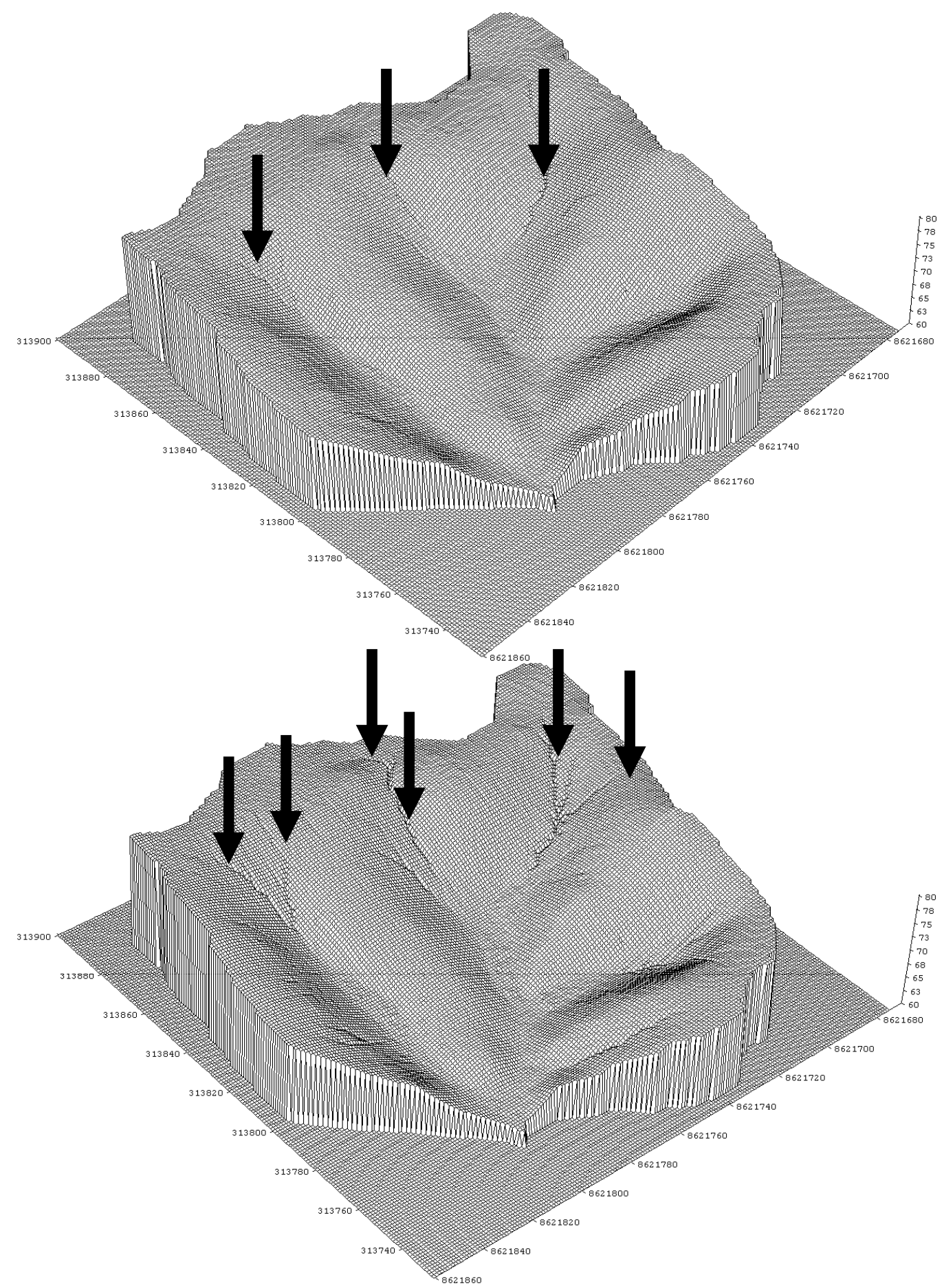

Figure 3. Subcatchment extracted from the modelled domain of the Tin Camp Creek subcatchment demonstrating the initiation of gullies at 5 years (top) and at 50 years (bottom) using $\mathrm{C} 1$ parameters.

In August 2002, gullies in the study catchment were initially mapped. Prior to the field program the entire catchment had been burnt, resulting in a near complete absence of groundcover, thus greatly enhancing the ability to locate and quantify erosion feature dimensions. To locate and measure gullies, the catchment was systematically traversed by foot along all drainage lines to the catchment divide. In this study, a gully was defined as an incision in a drainage line that was clearly degraded, with a well-defined break in slope in the channel with a vertical or near vertical headcut greater than $0.2 \mathrm{~m}$, whether the incision was continuous downslope or not. While others have defined gullies as having deeper incisions (i.e. Poesen et al. (2003) use $0.5 \mathrm{~m}$ as the minimum depth of a gully), here a shallower depth is used as smaller incisions are precursors to 
larger erosion features. Depth and width of all gullies were measured and length was measured only when the gully was clearly discontinuous. Other features, such as scour holes, located in the bed of the channel downstream of the gully head were also measured, as well as a series of small slumps located in the catchment headwaters at the tips of first-order streams. The field investigation found 140 individual points of incision within the 50ha catchment (Hancock and Evans, 2010) (Table 1).

The native vegetation is open dry-sclerophyll forest and composed of a mixture of species dominated by Eucalyptus and Acacia species. Melaleuca spp. and Pandanus spiralus are also found in the low-lying riparian areas with an understorey dominated by Heteropogon contortus and Sorghum spp. There is vigorous growth of annual grasses during the early stages of the wet season providing a thick mulch. Cover afforded by vegetation is often reduced by fire (both naturally occurring and lit with incendiaries) during the dry season, which enhances the potential for fluvial erosion. In recent years the site has been burnt every second year (Table 1).

From this investigation, 39 representative erosion features covering the entire catchment were selected for long-term monitoring. Thirty-four of these were gully heads and 5 were scour holes located in the channel downstream of a channel head. The selected erosion features covered a range of sizes from rills up to large gullies. The features had developed in a range of materials from soil in the lower reaches through to rocky colluvium in the upper reaches of the catchment. Since the initial data collection in 2002, the field

Table 1. Field data for the measured gullies at Tin Camp Creek.

\begin{tabular}{ccc}
\hline & Depth $(\mathbf{m})$ & Width $(\mathbf{m})$ \\
\hline average & 0.63 & 1.50 \\
stand. dev. & 0.25 & 1.13 \\
median & 0.60 & 1.15 \\
minimum & 0.3 & 0.2 \\
maximum & 1.35 & 5.6 \\
\hline
\end{tabular}

site has been visited annually (except for 2003 and 2010) with erosion feature dimensions and movement measured (Table 2).

Erosion and denudation rates have been established for the catchment using a variety of different methods. An assessment using the fallout environmental radioisotope caesium-137 $\left({ }^{137} \mathrm{Cs}\right)$ as an indicator of soil erosion status for two transects in the catchment produced net soil redistribution rates between 2 and $13 \mathrm{tha}^{-}$ ${ }^{1} \mathrm{y}^{-1}\left(0.013-0.86 \mathrm{~mm} \mathrm{y}^{-1}\right)$ (Hancock et al., 2008). The measured erosion rates, using ${ }^{137} \mathrm{Cs}$, for the upper hillslopes of the study area compare favourably with that of overall denudation rates for the area ( 0.01 to 0.04 $\mathrm{mm} \mathrm{y}^{-1}$ ) determined using stream sediment data from a range of catchments of different sizes in the general region (Erskine and Saynor, 2000). Soil production rates of $0.02 \mathrm{~mm} \mathrm{y}^{-1}$ have been determined for the study site which approximate the regional denudation rate (Heimsath et al., 2010).

\section{THE SIBERIA LANDSCAPE EVOLUTION MODEL}

SIBERIA is a mathematical model that simulates the geomorphic evolution of landforms subjected to fluvial and diffusive erosion and mass transport processes (Willgoose et al., 1991). The model links widely accepted hydrology and erosion models under the action of runoff and erosion over long-time scales. Hence it can be used as a tool to understand the interactions between geomorphology and erosion and hydrologic process because of its ability to explore the sensitivity of a system to changes in physical conditions, without many of the difficulties of identification and generalisation associated with the heterogeneity encountered in field studies. The sediment transport equation of SIBERIA is

$$
\mathrm{q}_{\mathrm{s}}=\mathrm{q}_{\mathrm{sf}}+\mathrm{q}_{\mathrm{sd}}
$$

Table 2. Change in depth of erosion features at Tin Camp Creek from 2002 to 2009 and SIBERIA simulation data for $\mathrm{C} 1$ and $\mathrm{C} 2$ parameters after 50 years. All dimensions are in metres.

\begin{tabular}{cccc}
\hline & $\begin{array}{c}\text { Field } \\
\text { data }\end{array}$ & $\begin{array}{c}\text { SIBERIA C1 } \\
\text { parameters }\end{array}$ & $\begin{array}{c}\text { SIBERIA C: } \\
\text { parameters }\end{array}$ \\
\hline average & 0.1 & 0.06 & 0.06 \\
stand. dev. & 0.21 & 0.06 & 0.04 \\
median & 0.1 & 0.06 & 0.064 \\
minimum & -0.55 & -0.09 & 0.07 \\
maximum & 0.70 & 0.18 & 0.13 \\
\hline
\end{tabular}

where $\mathrm{q}_{\mathrm{s}}\left(\mathrm{m}^{3} / \mathrm{s} / \mathrm{m}\right.$ width$)$ is the sediment transport rate per unit width, $\mathrm{q}_{\mathrm{sf}}$ is the fluvial sediment transport term and $\mathrm{q}_{\mathrm{sd}}$ is the diffusive transport term (both $\mathrm{m}^{3} / \mathrm{s} / \mathrm{m}$ width). 
The fluvial sediment transport term $\left(\mathrm{q}_{\mathrm{sf}}\right)$, based on the Einstein-Brown equation, models incision of the land surface and can be expressed as:

$$
\mathrm{q}_{\mathrm{sf}}=\beta_{1} \mathrm{q}^{\mathrm{m}_{1}} \mathrm{~S}^{\mathrm{n}_{1}}
$$

where $\mathrm{q}$ is the discharge per unit width $\left(\mathrm{m}^{3} / \mathrm{s} / \mathrm{m}\right.$ width), $\mathrm{S}$ (metre/metre) the slope in the steepest downslope direction and $\beta_{1}, m_{1}$ and $n_{1}$ are calibrated parameters.

The diffusive erosion or creep term, $\mathrm{q}_{\mathrm{sd}}$, is

$$
\mathrm{q}_{\mathrm{sd}}=\mathrm{DS}
$$

where $\mathrm{D}\left(\mathrm{m}^{3} / \mathrm{s} / \mathrm{m}\right.$ width) is diffusivity and $\mathrm{S}$ is slope. The diffusive term models smoothing of the land surface and combines the effects of creep and rainsplash.

SIBERIA does not directly model runoff $\left(\mathrm{Q}, \mathrm{m}^{3}\right.$ - for the area draining through a point) but uses a sub-grid effective parameterisation based on empirical observations and justified by theoretical analysis which conceptually relates discharge to area (A) draining through a point as

$$
\mathrm{Q}=\beta_{3} \mathrm{~A}^{\mathrm{m}_{3}}
$$

where $\beta_{3}$ is the runoff rate constant and $\mathrm{m} 3$ is the exponent of area, both of which require calibration for the particular field site.

For long-term elevation changes it is convenient to model the average effect of the above processes with time. Accordingly, individual events are not normally modelled but rather the average effect of many aggregated events over time are quantified. Consequently, SIBERIA describes how the catchment is expected to look, on average, at any given time. A more detailed description of SIBERIA can be found in Willgoose et al. (1991).

\subsection{SIBERIA input parameters}

Before SIBERIA can be used to simulate soil erosion the sediment transport and area-discharge relationships require calibration. The fluvial sediment transport equation is parameterised using input from field sediment transport and hydrology data. For this study the SIBERIA model was calibrated from field data collected at Tin Camp Creek from a series of rainfall events. Two catchments of size $2032 \mathrm{~m}^{2}$ (catchment C1) and 2947 $\mathrm{m}^{2}$ (catchment $\mathrm{C} 2$ ) with average slopes of $19 \%$ and $22 \%$ respectively were instrumented during the wet season of 1990. Both sites are incised and channelized and are representative of the overall 50 ha catchment. The study sites were monitored during rainfall events in December 1992. At this time the catchments had a good covering of spear grass, which quickly regenerates each wet season.

To calibrate the erosion and hydrology models, complete data sets of sediment loss, rainfall and runoff for discrete rainfall events in both catchments were collected allowing calibration for the two individual catchments. Using these individual data sets parameter values of $\beta_{1}=5226, \beta_{3}=0.79, \mathrm{~m}_{3}=0.1, \mathrm{~m}_{1}=1.70$, $\mathrm{n}_{1}=0.69$ and $\beta_{1}=1440, \beta_{3}=0.83, \mathrm{~m}_{3}=0.1, \mathrm{~m}_{1}=1.69, \mathrm{n}_{1}=0.69$ were determined representing annual hydrology and sediment transport rates for catchments $\mathrm{C} 1$ and $\mathrm{C} 2$ respectively. While no field data exists for diffusion or hillslope creep for the area, a value of 0.0025 where length units are metres and time units are years (Hancock et al., 2000; 2002) has been used for previous studies in the area and is used here. A description of the parameters and this parameterisation process is described in detail by Evans et al. (2000) and Hancock et al. (2000). Boundary conditions for the simulations were such that all areas within the catchment boundary were allowed to erode and a series of outlets allowed sediment to exit from the domain.

SIBERIA uses a DEM to capture hillslope and catchment geomorphology. A regular 1m grid DEM of the area was created using digital photogrammetry and allows the incorporation of features such as the gully head and associated incised channels into the DEM providing a reasonable approximation of any erosion feature as it is less than the average width of the erosion feature (Figure 2 and 3, Table 1).

\section{RESULTS AND DISCUSSION}

All simulations were run using the 1m DEM described above. Individual simulations used the C1 and C2 parameters. Qualitatively, the simulations produce considerable incision along the main drainage lines having 
a well defined headcut and banks similar to the field data. All major drainage lines exhibited incision which grew through time along paths of concentrated flow (Figure 3). Several incisions have also spontaneously generated in depressions leading from the main drainage line. In the initial decades of the simulation the gullies advance along the main drainage lines with a well-defined headcut and banks. Over time the headcut reaches its proximal extent, the banks merge into the surrounding hillslope and a more rounded landscape results.

The incisions grow annually such that at 5 years only a small amount of incision can be observed but at 50 years is very well defined (Figure 3). Branching of the incision can be observed following main drainage lines and continues to heads of the first-order streams. Differences between erosion patterns and rates for the $\mathrm{C} 1$ and $\mathrm{C} 2$ parameter sets (Table 2, Figure 4) can be clearly observed with the $\mathrm{C} 1$ parameters producing a less incised network than the $\mathrm{C} 2$ data set demonstrating a sensitivity of the model to its parameterisation. Qualitatively these simulated features compare well to field observation.

At 50 years the model produces an average incision depth of $0.5 \mathrm{~m}$ and $0.42 \mathrm{~m}$ respectively for the $\mathrm{C} 1$ and $\mathrm{C} 2$ parameter simulations respectively approximating the field data measurements $(0.63 \mathrm{~m}$, Table 1$)$ and field mapped extent of the gullies and dimensions (Table 2). Maximum depth of incision was $0.95 \mathrm{~m}$ and $0.76 \mathrm{~m}$ respectively for the $\mathrm{C} 1$ and $\mathrm{C} 2$ parameter simulations respectively this being less than the maximum values observed for field data. Nevertheless, this field measurement was found for a gully lower down in the catchment which had developed in depositional material different to that for which the model parameters had been determined for.

While it appears SIBERIA matches the field measurement of the gullies at 50 years the simulations were continued for 1000 years. At the end of the 1000 year simulations, the gullies are at their maximal headward advance and have lost their well-defined banks and have largely merged into the surrounding hillslope. Geomorphologically there is little difference between the simulations with average elevation, hypsometric curve, area-slope relationship, cumulative area distribution, Strahler statistics very similar.

Erosion (denudation) rates for the catchment are 0.21 and $0.09 \mathrm{~mm}$ $\mathrm{yr}^{-1}$ on average over the duration of the simulation for $\mathrm{C} 1$ and $\mathrm{C} 2$ parameters respectively (Figure 4). Both erosion rates are higher than the regional denudation rate

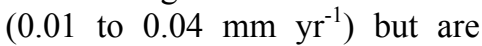
within the range of values for the catchment determined from ${ }^{137} \mathrm{Cs}$ (0.013-0.86 mm $\left.\mathrm{yr}^{-1}\right)$. This suggests that erosion rates predicted by the model are reliable.

\section{CONCLUSION}

The field and modelling results demonstrate that the entire catchment is at risk of gullying and is likely to result in landscape instability over decadal to centennial time scales. It is postulated that this catchment is at an erosion threshold where rapid advance of the gullies will commence once a threshold is crossed. This has implications for disturbed landscapes and reconstructed postmining landforms in the study area where the soil surface is new and pedogenesis is only beginning. It should be recognised though that the natural catchment examined here is very different to that of a post-mining landscapes where there is no bedrock impeding the downward movement of soil water and therefore allowing plant roots to penetrate deeper providing enhanced surface stability and a more robust system more with enhanced erosion resistance.

Due to the complexity of both qualitatively and quantitatively understanding the gullying process, considerable research has focussed on individual gullies processes or systems. A significant advantage of LEMs is that they can examine landscape features such as gullies across a range of spatial scales from 
individual erosion features (Hancock et al., 2000) to whole catchments such as that examined here. This modelling ability therefore allows the gully to be considered not just as an individual feature but as a feature of a complex system within a catchment. To model gully initiation and development the correct process or processes (i.e. fluvial and or diffusive erosion) must be indentified, model developed and calibrated and then results verified. In this case the combination of a fluvial and diffusive sediment transport model coupled together on a DEM grid that actively allows the landscape to evolve provides an acceptable qualitative and quantitative match with the field data.

\section{ACKNOWLEDGMENTS}

The traditional owners of the land where the study site is located, Parks Australia North, The Northern Land Council and Supervising Scientist Group staff, especially Mouse Saynor, Garry Fox, Dene Moliere, John F Lowry, Grant Staben and Bryan Smith are thanked for their cooperation and assistance. This paper was largely written while on SSP leave at Oregon State University.

\section{REFERENCES}

Coulthard, T. (2001). Landscape evolution models: a software review, Hydrological Processes, 15:165-173.

Erskine, W., Saynor M. (2000). Assessment of the off-site geomorphic impacts of uranium mining on Magela Creek, Northern Territory, Australia, Supervising Scientist Report 156, Supervising Scientist, Darwin.

Evans, K., Willgoose, G., Saynor, M., Riley, S. (2000). Post-mining landform evolution modelling. I. Derivation of sediment transport model and rainfall-runoff model parameters. Earth Surface Processes and Landforms. 25(7), 743-763.

Hancock, G., Willgoose, G., Evans, K., Moliere, D., Saynor, M. (2000). Medium term erosion simulation of an abandoned mine site using the SIBERIA landscape evolution model. Australian Journal of Soil Research, 38, 249-263.

Hancock, G., Willgoose, G. (2002). The Use of a Landscape Simulator in the Validation of the SIBERIA Landscape Evolution Model: Transient Landforms. Earth Surface Processes and Landforms, 27, 1321-1334.

Hancock, G., Evans, K. (2010). Channel and hillslope erosion - an assessment for a traditionally managed catchment, Earth Surface Processes and Landforms, 13: 1468-1479, DOI: 10.1002/esp.2043.

Hancock, G., Loughran, R., Evans, K., Balog, R. (2008). Estimation of soil erosion using field and modelling approaches in an undisturbed Arnhem Land catchment, Northern Territory, Australia, Geographical Research, 46(3): 333-349.

Heimsath, A, Fink, D., Hancock, G. (2009). The 'humped' soil production function: eroding Arnhem Land, Australia, Earth Surface Processes and Landforms, 34: 1674-1684.

Poesen, J., Nachtergaele, J., Verstraeten, G., Valentin, C. (2003). Gully erosion and environmental change: importance and research needs, Catena, 50: 91-133.

Saynor, M., Erskine, W., Evans, K., Eliot, I. (2004). Gully initiation and scour holes in the vicinity of Jabiluka Mine, Northern Territory, Australia, Geografiska Annaler, 86(A):191-203.

Willgoose G, Bras R, Rodriguez-Iturbe I. (1991). A physically based coupled network growth and hillslope evolution model: 1 Theory, Water Resources Research, 27(7), 1671-1684. 